\title{
«Basically, I am here to help you»
}

\author{
Police conversation interventions in the prevention \\ of radicalisation and violent extremism as a pastoral \\ technique of power
}

Kristin Engh Førde, PhD, postdoctoral fellow, Centre for Gender Research, University of Oslo, previously Researcher II, Norwegian Centre for Violence and Traumatic Stress Studies.

Arnfinn J. Andersen, PhD, Researcher II, Norwegian Centre for Violence and Traumatic Stress Studies.

\begin{abstract}
I denne artikkelen undersøkes bekymringssamtalen, som ofte blir omtalt som et sentralt verktøy i norske myndigheters arbeid med å forebygge radikalisering og voldelig ekstremisme. Slike samtaler blir gjennomført med personer som er antatt å være i risiko for radikalisering. Hensikten er å innhente informasjon, korrigere atferd, identifisere behov for hjelp, samt å tilby hjelp dersom det trengs. Inspirert av Foucault og hans tenkning om pastoralmakt analyserer vi bekymringssamtalen som myndighetsutøvelse, der til dels motstridende agendaer - av statlig kontroll og statlig omsorg - kommer sammen i det som konseptualiseres som «bekymring». Videre argumenterer vi for at bekymringssamtalen eksemplifiserer og synliggjør mer overordnede dilemmaer og konflikter i myndighetenes forebyggingsinnsats på dette feltet, hvor bekymring gir mening og legitimitet til det vi ser som en problematisk sammenstilling av omsorgs- og kontrolltiltak og av sosialpolitiske og sikkerhetspolitiske agendaer.
\end{abstract}

\begin{abstract}
In this article we set our sights on what is often referred to as a key instrument for countering violent extremism in Norway, the conversation of concern [Bekymringssamtale in Norwegian], usually referred to in English as the police conversation intervention. The conversation is conducted with individuals assumed to be at risk of radicalisation with the aim of obtaining information, modifying behaviour, identifying any needs for help, and offering help if needed. We argue that this intervention clearly demonstrates certain dilemmas and conflicts inherent in the Norwegian Government's recent policies on counter-extremism, where the concept of «concern» [bekymring] encompasses control and care, and includes agendas related to se-
\end{abstract}


curity and welfare, respectively. Applying a Foucauldian conceptual framework, we analyse the conversation of concern as a technique of pastoral power in which conflicting agendas interact in problematic ways, and the exercising of state power and control is neutralised through a notion of a general common good; "concern».

\section{Keywords}

Radicalisation; counter-extremism; prevention policing; concern; police conversation intervention; governmentality; pastoral power

\section{Introduction}

Like most western countries, Norway has stepped up its efforts to curtail terrorism and political violence in the last decade. An important - and novel - aspect of this intensified focus is that official activities are no longer limited to preventing and mitigating terrorism and its harmful effects. These new efforts, as they are presented in the Norwegian Government's Action Plans from 2010 (Ministry of Justice and Public Security, 2010) and 2014 (Ministry of Justice and Public Security, 2014), also target what are considered the underlying causes of terrorism, i.e. the process of radicalisation, which is assumed to lead to violent extremism and therefore terror and violence. In the 2014 Action Plan (Ministry of Justice and Public Security, 2014) radicalisation is defined as «a process whereby a person increasingly accepts the use of violence to achieve political, ideological or religious goals» (page 7). While we, like many scholars, have serious reservations about the radicalisation concept, such a critique is not our main concern here. In this article, radicalisation is not used as an analytic concept, i.e. it is not meant to reflect our understandings of the problems, events and individuals described. What we are interested in is its role as a problem framing for the actors involved. Previously, we have argued that the concept of radicalisation remains somewhat ambiguous, even to police specialising in preventing the phenomenon (Førde and Andersen, 2018). Here, we will elaborate on some of the implications of such ambiguity.

Until a decade ago, counter-terrorism was primarily the responsibility of security services in Norway (Lid et al., 2016). At present, a larger segment of society has been enlisted to prevent radicalisation and violent extremism, including both governmental institutions and civil society. Our focus, local police forces, have been assigned a so-called 'key role' in this broad-based effort, adding radicalisation and violent extremism to the police's generally increased prioritisation of crime prevention, rather than reaction in response to it. This approach was developed from the 1950s until the present day (Balchen, 1998), and stated in the Police act since 1995.

One effect of articulating the problem as radicalisation rather than terror is that more public agencies will be tasked to investigate a greater num- 
ber of individuals. More aspects of these individuals' lives will be open to scrutiny, including utterances and practices normally protected in a liberal democracy.

This shift has been met with remarkably little reaction in Norwegian society, despite the profound challenges it poses to liberal democracy. These challenges are rarely addressed in public debate on prevention efforts, and, further, the framing of the problem seems to be largely taken for granted. The conversation is limited to how to tackle radicalisation; the notion that radicalisation is indeed the problem remains unexamined.

In the wake of the policy shift, scholars of various countries, including those in the Nordics, have taken an interest in the prevention of radicalisation and violent extremism, concentrating mainly on practical and tactical aspects of the prevention efforts (for examples see Agerschou, 2014, Andersson and Mattsson, 2017, Bertelsen, 2015; 2018, Dalgaard-Nielsen, 2013, Hemmingsen, 2015, Lindekilde, 2010, Ranstorp and Hyllengren, 2013, Sivenbring and Malmros, 2019, Vidino and Brandon, 2012). Although this literature leaves the premises of the prevention policies largely unscrutinised, there are exceptions (Heath-Kelly, 2013; 2017, Mattsson et al., 2016, Mattson, 2019). Notable among these is research inspired by the branch of extremism research often referred to as Critical Terrorism Studies (Bjørgo and Gjelsvik, 2015). These scholars problematise the conceptualisation and language of state policies concerned with terrorism, political violence and extremism. (Borum, 2011; 2012, Heath-Kelly, 2013; 2017, Kundnani, 2012, Sedgwick, 2010). As such, they focus on the discourses influencing institutional actions, rather than the characteristics or motivations of individuals presumed to be radicalised or extremist. This approach has inspired our investigation of prevention efforts in Norway.

Our research is an addition to the growing corpus of studies relating to governmental policy and practice in Norway, based on the action plans from 2010 and 2014 (Bråten and Sønsterudbråten, 2017, Carlsson, 2018, Fangen and Carlsson, 2013, Førde and Andersen, 2018, Guribye and Grødum, 2018, Lid et al., 2016, Lid and Heierstad, 2019, Sunde, 2013). However, in our opinion the debate lacks a critical examination of the relationship between tensions and dilemmas in day-to-day efforts, and implicit premises suggested by the language used in the policy discourse. This article aims to provide that critique, by means of examining prevention work conducted by local police.

In previous work we have explored the category «concern» [bekymring in Norwegian], which occurs frequently and broadly in the field, and is employed both in government policies (such as the action plans) and practical preventive work (Førde and Andersen, 2018; 2019). Concern is neither thematised nor problematised in these contexts; rather, it works as a vague and flexible term, denoting a wide range of phenomena related to potential risk of radi- 
calisation and/or extremism. We argue that this flexibility makes concern key to the framing of the overall preventive effort, in which the state's conflicting agendas can merge into one category which, connoting intimacy and emotion, is more suggestive of empathy and care, than control. Such a framework, we argue, heavily downplays dilemmas related to the inherent conflict between societal security and democracy (Førde and Andersen, 2019).

Our work so far has aimed to «unpack» and highlight the links between tensions and dilemmas experienced by the people whose everyday work is affected by the new policy, and the overarching challenges and contradictions at the political and societal level, as discussed above. In this article, we will further unpack, and elaborate on our argument that concern encompasses the state's agendas of care and of control alike, running the risk of blurring their boundaries and differences, and at times even placing the former in an instrumental relationship to the latter.

To this end, we will examine the Norwegian police's «conversation of concern,» an intervention conducted with individuals considered to be at risk of radicalisation and/or violent extremism. The National Police Directorate (POD) has issued guidelines for these interventions, indicating when, with whom, why and how such interventions should be employed (The National Police Directorate, 2011). The measure is considered a key instrument for countering extremism in Norway. It is also, we argue, an instance wherein the inherent tensions of the concern approach play out in an especially condensed and entangled manner. Care and control come together temporally and spatially through an encounter between a police officer and the person assumed to be at risk. The conversation, as we see it, has a double agenda. While it provides an opportunity for consideration, care and trust building, it also provides police access to intelligence information with, potentially, farreaching consequences for the subject and/or their network. In many cases this latter agenda remains tacit (Førde and Andersen, 2018).

\section{Pastoral power as a technology of governmentality}

The Foucauldian governmentality framework (Foucault, 1984; 2007, Foucault and Gordon, 1980) assists us in our argument. Governmentality is a conceptualising of state power as not only exercised through top-down governance, but through the individual's own self-governance in accordance with what Foucault calls truth or knowledge regimes. Here Foucault suggests that knowledge and truth are produced by, and function within, structures of power, and that the fundamental premises of these «truth regimes» are hardly questioned. We take the shift from «terrorist hunt» to «concern» to represent a change in a truth regime; in our case the assumption being that «radicalisation» is the cause of extremism, or that extremist views are the cause of extremist violence. 
Experts - those with special access to knowledge - are crucial to governmentality in modern states (Rose and Miller, 1992), and it is the work of such experts that we analyse here. We have found it useful to think about this in terms of pastoral power, a term introduced by Foucault to theorise a particular form of expert power technique, rooted in old Christian institutions, yet finding its way into Western neoliberal states as a distinctive operationalisation of governmentality (Foucault, 1982). Of particular interest is that pastoral power has been said to «work through certain individuals - pastors - in instructing, caring for, and deriving legitimacy from the communities they serve» (Martin and Waring, 2018, page 2). As a technology of governmentality, the pastor exercises a normalising discipline on the individual, combining surveillance and discipline on the one hand, and care for the well-being of the individual on the other. In their encounters with individuals of concern, the role of police is both crucial and paradoxical. The police aim to foster a trusting relationship, through which they can pursue conflicting objectives pertaining to policing and welfare. The concept of pastoral power helps us illuminate the link between their role, and concern as a truth regime. Foucault saw the employment of pastoral techniques of power combined with a liberal discourse of rights as the «cunning - or even demonic - combinatorics of the welfare state» (Foucault 1982 in Villadsen, 2007, page 159). Considering concern as such a combination, we explore the interplay between care and control within this approach. We argue that combining the two is problematic as the former becomes secondary, and at times even instrumental, to the latter.

\section{Methodology}

This article draws on findings from a larger study of efforts by local police to prevent radicalisation and violent extremism in Norway (Førde and Andersen, 2018). The Government's Action Plan from 2014 (Ministry of Justice and Public Security, 2014) tasked the police districts with the earmarking of personnel for this prevention effort. Thus, at the time of our study, all districts had recruited (by appointment or application) officers who worked with prevention of radicalisation and violent extremism. Their positions were full-time, or part-time combined with other police work, according to the perceived need in the district in question. Our study was a qualitative investigation of the work carried out by these police officers, usually referred to by the police themselves as «radicalisation contacts». Assisted by the National Police Directorate, we gained access to four police districts, in which we collected data through individual interviews and participant observation over a period of seven months in 2016 and 2017. All officers working actively and extensively with cases where concern had been raised were asked to participate in a semi-structured individual interview. Out of these, 12 - four women and 
eight men - agreed and were interviewed. Four of the participants held the middle manager position of «radicalisation coordinator», entailing supervision of other radicalisation contacts. They were interviewed a second time in order to clarify issues related to the organisation of the work. All participants were in their thirties or forties, with a seniority within the police ranging from 2 to 26 years. The interviews, lasting between 75 and 150 minutes, were recorded and transcribed. Among other questions concerning their work as radicalisation contacts, we asked the officers to share their experiences of, and reflections upon, the conversation of concern as a prevention tool.

We (mostly KEF, but on occasions both authors) also collected data by attending and observing a total of 18 internal meetings in the four police districts. In these meetings, lasting from one to three hours, radicalisation contacts gathered to discuss their work, including on-going cases. The majority of meetings were in the two districts most active with counter-extremism activities. Through observing discussions and interactions in meetings we gathered additional data on the role of the conversation of concern, e.g. how it was discussed among colleagues, in which situations it was suggested as a tool, and how concrete conversations were experienced and evaluated by the police officers. Meetings were documented through handwritten field notes which were later typed and edited. Unfortunately, the police declined our request to observe actual conversations of concern, due to tactical concerns. Interviewing the individuals summoned for conversations also fell outside the scope of our study.

Thus, our empirical material is the police officers' accounts of, and reflections upon, the intervention tool. In our analysis we systematically searched for and categorised recurring practises and discourses, by which the police, as key representatives of the Norwegian prevention effort, give meaning and legitimacy to their prevention work in general, and the conversation of concern in particular.

The conversation of concern - a key tool in new prevention efforts

The conversation of concern is crucial for the police. (...) It is our chief instrument [in preventing radicalisation and extremism].

(Radicalisation Coordinator)

The view of the conversation of concern as a «chief instrument» for the Norwegian police in preventing radicalisation and violent extremism, clearly echoes our own findings that it is key to overall preventive efforts. It was frequently employed in all police districts studied, by all the interviewed radicalisation contacts and - as far as we could observe - with a large share of the so-called «cases for concern» reported to the local police. Persons raising concern were summoned, usually to the police station, for what was meant to be a dialogue, as opposed to an interrogation, during which the issue of concern could be addressed and discussed between the police and the individual. 
For decades, such structured conversations between Norwegian police and youths and their parents have been a key tool in preventive policing. Dialogue as a preventive police instrument was developed alongside the efforts to dissolve a right-wing extremist group based in Oslo, Norway's capital, between 1995 and 1997 (Carlsson and Lippe, 1999), and proved to be highly successful for its intended purpose (Bjørgo and Gjelsvik, 2015). Since then the tool has been used broadly in prevention policing targeted at youth generally. Furthermore, it has been touted as a key preventive measure to employ against all varieties of extremism. The intervention has even been promoted abroad as a "good practice» and recommended for prevention efforts in other countries. ${ }^{1}$

The conversation of concern has gained legislative acceptance for use as a preventive measure specifically targeting children and youths. Correspondingly, the Norwegian Police Act (section 13, subsections 4 and 5) authorises police to summon an individual for a conversation of concern. The official guidelines recommend the conversation of concern «as a measure when a child exhibits unwanted/criminal behaviour that could evolve into a criminal career» (The National Police Directorate, 2011, page 12). Adults may be summoned for a conversation as well. However, unlike minors, adults are not obligated to attend. ${ }^{2}$

The guidelines consequently portray the intervention as one of «dialogue». In the foreword it is stated:

It is vital to create a setting in which those who are involved can speak frankly, so that an overview of the situation can be gained and the parties can arrive at a common understanding of the problem. Only then can we start trying to move things in the right direction (ibid, page 5).

Instead of a disciplinary act of power from the state, this portrays the intervention as an arena for dialogue between parties assumed to have a mutual interest, i.e. moving in the «right direction», under the guidance of a police officer who is at once stern and friendly. Thus, the pastoral qualities of the conversations, as we shall see them described by our informants, seem to be highly intentional from their theoretical institutional outset.

We will now examine more closely how the radicalisation contacts presented and reflected upon their own practice concerning the conversation intervention.

1. A recent example of such promotion can be found in the Issue Paper from the EU Radicalisation Awareness Network dated 15.01.2020, authored by Tore Bjørgo, probably the most influential Norwegian researcher in the field: https://ec.europa.eu/home-afa fairs/sites/homeaffairs/files/what-we-do/networks/radicalisation_awareness_network/ about-ran/ran-pol/docs/ran_pol_lessons_from_crime_prevention_012020_en.pdf

2. This fact, that preventive measures are voluntary for adults, poses a challenge to the police's prevention of radicalisation and violent extremism in general and to the use of the conversation of concern in particular. We discuss this dilemma in more depth in Førde and Andersen, 2018. 
Modes of herding: intelligence, deterrence and help

[The conversation of concern] is our primary means of getting in touch with people and getting to know them, so we can share what we can do for them while also making a sound assessment of them, which may lead us to say, "You know what, now that we have talked to you we no longer see any grounds for real concern». As such, it's a tool that helps us to make the right decisions, so that we don't waste our time working on or bothering the wrong people. It also [helps us] to employ the right methods in those cases we do pursue.

(Radicalisation Coordinator)

As indicated by this quote, and as we shall elaborate on, our informants portrayed the conversation of concern as having a complex set of intended purposes, which also varied from case to case. Obtaining information was often emphasised as the key objective (in the quote above, expressed in terms such as «making a sound assessment», "getting in touch with people and getting to know them»). Information obtained was meant to form the basis for police assessment of the person and their risk of becoming radicalised, associated with an extremist group or of committing extremist violence. Consequently, it could be claimed that even though the intervention was developed as, and is referred to as, a preventive measure, the key objective in many of the conversations discussed with us was related to intelligence gathering, understood as the systematic collection, analysis and assessment of information in support of strategic, operational and tactical decisions (The National Police Directorate, 2014). In turn, such information, notwithstanding the prevention context in which it was obtained, could be used in a process of criminal prosecution against either the subject or an associate of theirs.

The official guidelines state explicitly that the conversation should not bring up religion, politics or ideology; rather, it should address connections to extremist groups and factors (including psychosocial problems, health issues, unemployment, substance abuse, etc.) associated with increased risk of undesirable behaviour. The accounts of the radicalisation contacts, however, clearly suggest that these «off-limits» subjects did arise quite frequently and became a topic of conversation, although not necessarily as a result of a direct question from the police. The conversation was regularly used to clarify what was «behind» a specific incident, e.g. a social media post or participation in a protest, and in that sense was not very different from an interrogation, after all.

Aside from intelligence gathering, another traditional objective of the conversation was to serve as a warning or signal to the individual that the police were keeping an eye on them, in order to correct unwanted behaviour. One radicalisation contact shared his thoughts with us about his repeated conversations with a young man who had posed threats against politicians, presumably motivated by jihadist ideology: 
The first conversation was a way of saying, "l am here. I work in the department of prevention. Basically, I am here to help you. But l'd also like to say ... as a policeman, I have to let you know what you are doing is in fact a punishable offence.»

\title{
(Radicalisation contact)
}

The conversation was, thus, used as a means of deterrence, with the aim of bringing about behavioural adjustment, which in turn would «reduce the level of concern».

But, as this last quote («Basically, I am here to help you») clearly illustrates, in addition to the traditional police agendas of intelligence and deterrence, the conversation of concern was also meant to serve as an opening through which the police could offer what they themselves usually referred to as «help».

Counter to our observation that the key purpose was intelligence gathering, it was common for the radicalisation contacts to emphasise that their key purpose was to communicate their willingness and capacity to provide help. One radicalisation contact was even more explicit in this matter, explaining that he summoned individuals to let them know that:

\begin{abstract}
«I am here for you. If you need help related to housing, work, health, something about your family, anything, I have lots of contacts. I can help you. I can put you in touch with the right people. I can pass the information on if you like, or ask people to call you, if you need support or help, right?» I believe [communicating that we can help] is the most important thing we do in those interactions.
\end{abstract}

(Radicalisation contact)

Through our observations and interviews we were informed about several cases in which an initial conversation of concern resulted in repeated contact, where police officers assisted individuals considered at risk in a wide range of matters, such as finding employment or housing, opening a bank account, or seeing a doctor. In some cases radicalisation contacts ended up serving as liaisons in individuals' contact with social services, assisting with, for example, communicating needs or scheduling appointments. While the main purpose of the first conversation was to gather intelligence, the relationship that was established enabled the radicalisation contact to intervene and assist the person in ways assumed to not only improve their day-to-day circumstances, but also to counter any tendency towards extremism; in alignment with the police's overarching aim. As such it could be argued that the police officer in effect sometimes took on the tasks of a mentor, a preventative measure employed against radicalisation and violent extremism in many contexts, including in Norway at the time of the study. Mentor programmes even existed in some of the police districts studied, and some of the radicalisation contacts cooperated with such mentors. However, our observation that police did sometimes fill this role may indicate that the programmes were not fully operative or functional at the time. 
Police officers becoming de facto mentors, by way of conversations of concern, suggests that this intervention sometimes functions as a bridge between policing and social services. What surprised us was the extent to which the police themselves took on work usually performed by social workers, such as repeated conversations of support, accompanying individuals to medical appointments or assisting them in finding a place to live. In other cases, officers mapped out known difficulties with gaining the involvement of relevant agencies, such as Norwegian Labour and Welfare Administration (NAV), child welfare services or mental health services, before performing a coordinating role between the actors involved. In these cases the police often remained in the assigned key role, despite the required help being more strongly linked to social services. "Help», in turn, runs the risk of becoming an instrument of police pastoral power, a point to which we will return.

«They need to trust me» - building a pastoral relationship

In a way, it is about building a relationship. You kind of make the person have some trust in you. You need to be clear that you are a policeman and that sort of thing (...) but if I am going to follow up [it is necessary] that they come to trust me.

(Radicalisation contact)

As we touched on above, dialogue is one of the fundamental ideas behind the conversation of concern as a police tool. In order to achieve the conflicting objectives of care and control, as discussed, the police described it as essential to gain the trust of the person they were concerned about. This was often expressed in terms of «building a relationship», through which intelligence could be gleaned, and deterrence and/or help proffered. The following case, shared with us by a radicalisation contact, serves as an ideal example:

The cause of concern in this case was a young man considered to be in difficult circumstances, who had recently been observed in the company of well-known Islamist extremists. Initially a conversation of concern was conducted mainly to gather information about his contact with extremists, and assess the risk of radicalisation. This conversation led the police to «reduce concern». However the young man was still considered vulnerable and thus «easy prey» for extremist recruiters. Consequently, the radicalisation contact followed up with four or five additional conversations, in which he talked to the young man about his life in general, his life plans and opportunities, and provided support and advice. When evaluating this measure, the interdepartmental team responsible for the case concluded that repeated conversations of concern had helped the young man, partly because the radicalisation contact «had found the fine balance between representing an adult authority while also being adequately loyal and friendly». The «fine balance» referred to here could also be expressed in terms of pastoral power: a fine balance between control, care, and surveillance, and encouraging self-reflection and self-governance. It is important to note here that 
such pastoral relationships are considered key in all prevention policing directed towards youth, and are not unique to this field of prevention. In this field, however, we observed that the police also sought to foster such relationships where the persons of concern were adults.

The importance of nurturing a pastoral kind of relationship becomes even clearer in cases in which the radicalisation contacts considered the intervention unsuccessful. In one such example, a radicalisation contact told us about a conversation of concern conducted with a young adult who had been recruited to a well-known right-wing extremist group. The purpose of the conversation was not to clarify the concern, as police already knew of his association with the group. Rather, the conversation was intended to deter his extremist development. The radicalisation contact conveyed that he had held a measure of hope for «saving a person who was heading in the wrong direction». However, he explained that he had not succeeded in establishing trust and dialogue, and so perceived this conversation a failure. Nonetheless, he retained his belief in the conversation as a tool for correcting attitude and behaviour.

I still do have a sort of naïve and positive attitude, meaning that if you just repeat it enough times, sow the seeds of doubt a thousand times, you may eventually reach them. You just have to continue hanging in there. In this case, I'd like to have another conversation the week after, and then the week after that, until he has had enough. And then try to get him in again, just to show him that we do also care. (Radicalisation contact)

A single conversation of concern was thought insufficient to «turn the negative development around». As the radicalisation contact saw it, repeated conversations were necessary. Even then, the desired effect might not be achieved, but it might be possible to «sow doubt», i.e. to get individuals to question their perspectives, which could prove fruitful later. This example illustrates how agendas of care and control coalesce explicitly, in what this officer clearly saw as a mission of «helping». In fact, his described agenda was somewhat authoritarian: he wanted the young man to "come to his senses» and to submit to the values espoused as «right». He envisioned that a response to caring («showing that we care») could be elicited by, effectively, exerting authority, i.e. asking the young man to come to weekly meetings until «he had enough». We also find it interesting that the radicalisation contact identified himself as «naïve» and «positive»; characteristics which he believed to shape and motivate his professional choices (at another point he referred to himself as «optimistic»). The officer emphasised his «softer» caring traits, i.e. those with more empathetic value, as opposed to more traditional «harder» traits of control e.g. strength or acumen. Yet when placed in conflict, these harder traits - the control aspect of pastoral police power - take clear precedence over the softer traits. 


\title{
Help as an instrument of power - the problematic conflation of care and control
}

As suggested by the previous example, obtaining a sufficiently trusting relationship with the person of concern was often extremely challenging. It was acknowledged that this was, at least partly, due to the fact that the dialogue was initiated by the police; that is, the power apparatus of the state. For most people, being summoned to a conversation with the police is no trivial matter - regardless of any stated distinction from an interrogation. As already noted, the police we interviewed addressed such challenges by heavily emphasising the prevention aspect of the conversation, in order to convince the subject that the conversation was «innocuous» and, perhaps, even in their own interest. One police officer had this to say about how he motivated people to attend the conversation:

\begin{abstract}
We [make it clear that we] are preventers, we are interested in helping, we do not wish to ... We just want to make sure that the concern we have related to violence, among other things, is reduced. And we are not here to change your opinions. We will not act as «thought police».
\end{abstract}

(Radicalisation contact)

The prevention aspects are emphasised: «help» is the main objective, and opinions, per se, will not be problematised. It is even suggested that «reduced concern» is the most likely outcome of the conversation. In this portrayal preventive policing is to a large extent equated with social work («we are interested in helping»), and the conversation intervention is presented as harmless; hardly at all an encounter with the state apparatus. What must be assumed to be a conflict of interest between police and the individual is downplayed, and what remains is portrayed as a matter of common interest: to «reduce concern».

Yet, as mentioned, intelligence was in many cases more essential to the conversation than «help», and many conversations did in fact address opinions, faith and utterances, rather than violence. In fact, we also saw numerous examples in which offers of help were described as a means to motivate individuals to open up and provide the information sought by the police not necessarily only about the individual summoned, but also about other suspected extremists or groups, or any other information that could be instrumental for the police. In this sense, the relatively generous Norwegian welfare state resources - available to the police largely as an effect of the concern problem framing - were used as an instrument for intelligence gathering. In our opinion, this finding illuminates the problematic aspects related to the agendas of care and control being tightly interwoven, not only in the conversation of concern, but in all work performed in this field within the framework of concern. 


\section{Final discussion}

In this article we have discussed how the Norwegian local police employ, and reflect upon, the "conversation of concern»; a tool they regard as key to preventing radicalisation and violent extremism. We have described and discussed this intervention as a technique of power, highlighting the pastoral qualities of its multifaceted purpose, i.e. intelligence gathering, deterrence and providing help. We argue that there is an inherent dilemma in the position sought by police relative to the person of concern and the pastoral character of the relationship. The motive of the police is, on the one hand, to care, i.e. to employ measures to help to improve the life circumstances of marginalised individuals, and consequently minimise the risk of radicalisation and extremism. On the other hand, the conversation of concern also contains elements of a controlling nature, such as deterrence and, in particular, intelligence gathering. Thus, control and care are present at the same time, in the same room, on behalf of the same state agency and through the same individual. There is a downplaying of the conflict of interest between the summoned individual - who presumably seeks to limit their contact with the police - and the police themselves, who are seeking interaction with, and information from, the individual. We observed that the overall, mutual goal of «reducing concern» served to soften the sense of conflict.

We have also seen that these two agendas of pastoral power are linked in an instrumental manner: trust and cooperation gained through offers of caring assistance are used to facilitate the agenda of control, and in particular for intelligence purposes. Thus, a security-related agenda and a socio-political agenda merge, and the police assume the role of social worker and become a conduit to welfare services. Social and welfare services thus become a means with which to attain security policy goals. In the process, individuals of concern can, effectively, be prioritised in the distribution of these services.

We do not contend that concern from the police as a pastoral approach is altogether adverse. From our experience, framing prevention of radicalisation and violent extremism in such a way may enable a more holistic approach to mitigating extremism, capturing more of the highly complex phenomenon in terms of causes and manifestations. Nor do we mean to argue that pastoral-like power relations between the state and its citizens are in any way limited to the case of prevention of radicalisation and violent extremism. Ericsson (1996), for instance, has described how agendas of control and care have been entangled and negotiated against one another throughout the history of the Norwegian child welfare services. In recent years a number of studies have pointed out that health services and other state institutions have become favoured sites for governmentality in modern states (Martin and Waring, 2018).

Nonetheless, we do see the need to highlight some aspects of police concern as pastoral power that we find problematic, or interesting, and bring them under further scrutiny. In particular, how tasks and resources usually pertaining 
to social work are assigned to the police. This problematic accumulation of power technologies puts at risk the rule of law vis-à-vis individuals who become the object of the ambiguous concern of the police. Moreover, conflating the role of pastoral helper with the role of law enforcement discursively neutralises the inherent conflict of interest between the individuals' privacy and welfare, on the one hand, and the remaining key police agenda (investigation, criminal prosecution and punitive outcome), on the other. We argue that the regime of concern, as a whole, tends to conflate societal agendas of social welfare and security, and blur the fundamental tension between security and democratic values and rights, such as tolerance and freedom of speech. As we have seen, this is particularly manifest in the pastoral power work conducted by the police, although the dilemmas experienced by the police neither start, nor could possibly end, with them. To fully understand and address the problematic aspects of the pastoral role of the police, we must examine the knowledge regime in which this role resides, rather than perfunctorily assuming «radicalisation» to be the problem, and the joint prevention forces of governmental agencies, led by the police, the solution.

Kontaktoplysninger

Kristin Engh Førde: k.e.forde@stk.uio.no

Arnfinn J. Andersen: a.j.andersen@nkvts.no

\section{References}

Agerschou, T. (2014) Preventing radicalization and discrimination in Aarhus. Journal for Deradicalization,1. https://journals.sfu.ca/jd/index.php/jd/article/view/2

Andersson, R. and Mattsson, C. (2017) Från ord till handlingsplan: En rapport om kommunala handlingsplaner mot våldsbejakande extremism. Göteborg: Förvaltningshögskolan, Institutionen för pedagogik, kommunikation och lärande, Göteborgs Universitet.

Balchen, P.C. (1998) Politiets forebyggende arbeid: Begrensninger og muligheter. Nesbru: Vett og viten.

Bertelsen, P. (2015) Danish preventive measures and deradicalization strategies: The Aarhus model. Panorama: Insights into Asian and European Affairs, 1.

Bertelsen, P. (2018) Mentoring in anti-radicalization. LGT: A systematic assessment, intervention and supervision tool in mentoring, In Overland, G., Andersen, A.J., Førde, K.E., Grødum, K. and Salomonsen, J. (eds.) Violent Extremism in the 21st Century. Cambridge: Cambridge Scholar Publisher.

Bjørgo, T. and Gjelsvik, I.M. (2015) Forskning på forebygging av radikalisering og voldelig ekstremisme: En kunnskapsstatus. Oslo: Politihøgskolen.

Borum, R. (2011) Radicalization into violent extremism I: A review of social science theories. Journal of Strategic Security, 4.

Borum, R. (2012) Radicalization into violent extremism II: A review of conceptual models and empirical research. Journal of Strategic Security, 4.

Bråten, B. and Sønsterudbråten, S. (2017) Veiledningserfaringer. Forsøk med veiledning (ICDP) av foreldre med radikaliseringsbekymringer og foreldre i asylmottak FAFO-rapport 2017:02. Oslo: Forskningstiftelsen FAFO.

Carlsson, Y. (2018) Global challenges: Local solutions? The role of Norwegian municipalities in prevention of violent extremism, In Overland, G., Andersen, A.J., Førde, K.E., Grø- 
dum, K. and Salomonsen, J. (eds.) Violent Extremism in the 21st Century. Cambridge: Cambridge Scholar Publisher.

Carlsson, Y. \& Lippe, H.V.D. (1999) Velstandsbydelen og rasisme: Hva ble gjort for å løse opp et høyreekstremt ungdomsmiljø på Nordstrand i Oslo, 1994-1997. Rapport 1999:9. Oslo: NIBR.

Dalgaard-Nielsen, A. (2013) Promoting exit from violent extremism: Themes and approaches. Studies in Conflict and Terrorism, 2.

Ericsson, K. (1996) Barnevern som samfunnsspeil. Oslo: Pax.

Fangen, K. \& Carlsson, Y. (2013) Right-Wing extremism in Norway: Prevention and intervention, In Melzer, R. \& Serafin, S. (eds.) Right-Wing Extremism in Europe: Country Analyses, Counter-Strategies and Labor-Market Oriented Exit Strategies. Berlin: Friedrich Ebert Stiftung.

Foucault, M. (1982) The Subject and Power. Critical Inquiry, 8.

Foucault, M. (1984) The history of sexuality 1: An introduction. Harmondsworth: Penguin.

Foucault, M. (2007) Security, territory, population: Lectures at the Collège de France, 197778. Basingstoke: Palgrave Macmillan.

Foucault, M. and Gordon, C. (1980) Power/Knowledge Selected Interviews and Other Writings, 1972-1977. Brighton: Harvester press.

Førde, K.E. and Andersen, A.J. (2018) Bekymringsarbeidet. Dilemmaer og muligheter i lokal forebygging av radikalisering og voldelig ekstremisme i Norge. Rapport 4-2018. Oslo: Nasjonalt kunnskapssenter om vold og traumatisk stress.

Førde, K.E. and Andersen, A.J. (2019) Bekymring - hva er det og hva gjør det? In Lid, S. \& Heierstad, G. (eds.) Forebygging av radikalisering og voldelig ekstremisme: Norske handlemåter i møtet med terror. Oslo: Gyldendal.

Guribye, E. \& Grødum, K. (2018) Elusive youth: Recruitment issues in work to prevent radicalization among immigrant youth, In Overland, G., Andersen, A.J., Førde, K.E., Grødum, K. \& Salomonsen, J. (eds.) Violent Extremism in the 21st Century. Cambridge: Cambridge Scholars Publishing.

Heath-Kelly, C. (2013) Counter-Terrorism and the counterfactual: Producing the 'radicalisation' discourse and the UK PREVENT Strategy. The British Journal of Politics \& International Relations, 15.

Heath-Kelly, C. (2017) The geography of pre-criminal space: Epidemiological imaginations of radicalisation risk in the UK Prevent Strategy, 2007-2017. Critical Studies on Terrorism, 10.

Hemmingsen, A. (2015) The Danish approach to countering and preventing extremism and radicalization. Copenhagen: Danish Institute for International Studies.

Kundnani, A. (2012) Radicalisation: The journey of a concept. Race \& Class, 54.

Lid, S. and Heierstad, G. (2019) Forebygging av radikalisering og voldelig ekstremisme: Norske handlemåter i møtet med terror. Oslo: Gyldendal.

Lid, S., Søholt, S., Hansen, S.J., Heierstad, G. and Klausen, J.E. (2016) Forebygging av radikalisering og voldelig ekstremisme: Hva er kommunenes rolle? Rapport 2016:12. Oslo: NIBR.

Lindekilde, L. (2010) Forebyggelse af radikalisering, miskendelse og muslimsk minoritetsidentitet. Tidsskrift for Islamforskning, 4(2).

Martin, G.P. \& Waring, J. (2018) Realising governmentality: Pastoral power, governmental discourse and the (re)constitution of subjectivities. The Sociological Review, 66.

Mattson, C., Hammaren, N. \& Odenbring, Y. (2016) Youth 'at risk': A critical discourse analysis of the European Commission's Radicalisation Awareness Network Collection of approaches and practices used in education. Power and Education, 8.

Mattsson, C. (2019) Policing violent extremism: How the global war on terror meandered into local municipal policies in Sweden. SAGE Open. doi: 10.1177/2158244019837462

Ministry Of Justice And Public Security (2010) Collective security - a shared responsibility. Action plan to prevent radicalization and violent extremism. Retrieved from: https:// www.regjeringen.no/en/dokumenter/collective-security-a-shared-responsibi/id626613/ 
Ministry Of Justice And Public Security (2014) Action plan against radicalisation and violent extremism. Retrieved from: https://www.regjeringen.no/contentassets/6d84d5d6c6df47b38f5e2b989347fc49/action-plan-against-radicalisation-and-violent-extremism_2014.pdf

Ranstorp, M. and Hyllengren, P. (2013) Förebyggande av våldsbejakande extremism i tredjeland: Åtgärder för att förhindra att personer anslutar sig till väpnade extremistgrupper i konfliktzoner. Stockholm: Centrum för Assymmetriska Hot- og Terrorismstudier, Försvarshögskolan.

Rose, N. and Miller, P. (1992) Political power beyond the state: Problematics of government. The British Journal of Sociology, 43.

Sedgwick, M. (2010) The concept of radicalization as a source of confusion. Terrorism and Political Violence, 22.

Sivenbring, J., and Malmros, R.A. (2019) Mixing Logics: Multiagency Approaches for Countering Violent Extremism. Gøteborg: Segerstedt Institute of Gothenburg University.

Sunde, I.M. (ed.) (2013) Forebygging av radikalisering og voldelig ekstremisme på internett. Oslo: Politihøgskolen.

The National Police Directorate (2011) A guide to police conversation intervention. A dialogue promoting responsibility and positive change. Retrieved from https://www. regjeringen.no/contentassets/a5050923704d4615af1271c8258ebad5/bekymringssamtalen_engelsk.pdf

The National Police Directorate (2014) Intelligence doctrine for the police [Etterretningsdoktrine for politiet]. Retrieved from https://www.politiet.no/globalassets/05-om-oss/03-strategier-og-planer/etterretningsdoktrine.pdf

Vidino, L. and Brandon, J. (2012) Countering Radicalization in Europe. London: International Centre for the Study of Radicalization, King's College.

Villadsen, K. (2007) Magt og selv-teknologi: Foucaults aktualitet for velfærdsforskningen. Tidsskrift for Velferdsforskning, 10(3). 